\title{
The Matter of Quebec Movement: A Review on Canadian Domestic Politics
}

\author{
Fikry Muhammad Reza Al-Hasin ${ }^{1}$, Demeiati Nur Kusumaningrum ${ }^{2}$ \\ ${ }^{1,2}$ Center for Intermestic Studies (CIS), International Relations Department, University of \\ Muhammadiyah Malang, East Java - Indonesia \\ Email: fikrireza46@webmail.umm.ac.id \\ Submitted: 13 July 2020 | Accepted: 29 December 2020
}

\begin{abstract}
Previous research on the Quebec movement discussed the risks and interests of Quebec nationalism, the existence of various attempts to link cultural issues with the movement, and the reasons for disintegration and the influence of several variables such as the history and group formation towards a Quebec movement. However, this research focuses on how selfdetermination means to the Quebec movement influencing Canadian domestic politics and how the federal government deals with it. This study uses a constructivist approach to explain how Quebec's identity underlies its importance in the liberation movement and how its strategy affects Canada's political structure utilizing literature method. The research results show the Quebec movement developed a strategy by (1) creating a political discourse of "selfdetermination". The existence of the social movement turned into the Québécois political party which had a vision of controlling the province since the 1960s; (2) the existence of a social construction related to the problem of French identity as a non-Canadian culture. Support for these ideas is embodied in the form of regulation and propaganda in the public sphere. However, the Canadian government managed to maintain its political stability by adopting a middle way approach in dealing with the independence movement.
\end{abstract}

Keywords: Canada, Constructivist, Identity, Movement, Quebec.

\begin{abstract}
Abstrak
Penelitian sebelumnya mengenai gerakan Quebec mendiskusikan tentang resiko dan kepentingan nasionalisme Quebec, adanya berbagai upaya untuk menghubungkan isu budaya dengan gerakan, dan apa yang menjadi alasan disintegrasi serta pengaruh beberapa variabel seperti sejarah dan pembentukan kelompok menuju sebuah gerakan Quebec. Namun, penelitian ini berfokus pada bagaimana makna penentuan nasib sendiri bagi gerakan Quebec memengaruhi politik domestik Kanada dan pemerintah federal yang menanganinya. Penelitian ini menggunakan pendekatan konstruktivis untuk menjelaskan bagaimana identitas Quebec melandasi kepentingannya dalam gerakan pembebasan dan bagaimana strateginya mempengaruhi struktur politik Kanada menggunakan metode pustaka. Berdasarkan hasil penelitian, gerakan Quebec membangun strategi dengan (1) menciptakan wacana politik "self-determination". Eksistensi gerakan sosial berubah menjadi partai politik Québécois yang memiliki visi untuk menguasai wilayah provinsi sejak dekade 1960-an; (2) adanya konstruksi sosial yang berkaitan dengan masalah identitas Prancis sebagai budaya non-Kanada. Dukungan gagasan tersebut tertuang dalam bentuk regulasi dan propaganda di ranah publik. Namun, pemerintah Kanada berhasil menjaga stabilitas politik dengan menerapkan pendekatan jalan tengah dalam menghadapi gerakan kemerdekaan.
\end{abstract}

Kata Kunci: Kanada, Konstruktivis, Identitas, Gerakan, Quebec.

\section{INTRODUCTION}

Canada has experienced the issue of disintegration by Quebec movement as the matter to study international relations in America 
Region. Quebec movement represent political group that aimed to separate from Canadian government (Behiels, 2019; Changfoot et al., 2012, p. 773; Rocher, 2014, p. 26). The demand to separate itself from Canada has been going on since the 1960s through Quiet Revolution (Rocher, 2014, p. 26).

The Quiet Revolution started in the 1960s suggested by Jean Lesage as Premier of Quebec. He has reformed several sectors such as in education, social welfare, hydroelectric power, regional development and industrial sector (Behiels, 2019).

The Lesage government created a modern and secular Quebec province that took control of all social, health and education institutions, and succeeded in opening thousands of jobs for educated French-speaking communities and reducing the role of Canadianspeaking Canadians in Quebec. The modernization that focused on institutional, social, politic and economic different from the conservative way in the past (Rocher, 2014, p. 26).

The justification for Quebec's movement was historically etnonationalistic factors. It begins from the claim of its unique culture and the majority of French-speaking that is representing $78 \%$ of the provincial population were threatened by assimilation both by all Canadians and Anglophone culture in general (Guay, 2017, p. 21; Parti Québécois, 2020).

Quebec is one of thirteen provinces in Canada. Quebec is the second most populous province in Canada, after Ontario and the only province that has a majority population speaking French, with French as the only official language of the province (Statistics Canada, 2017). People speak their national language from inclination, doubtless; but also from self-interest which the cases of institutionalized bilingualism are rare and not exactly ever-lasting, except in countries where the linguistic minorities are associated with a clearly identified territory such as Quebec in Canada (Judt \& Lacorne, 2004, p. 4).

A lot of French Canadian wanted to have their own state, which used to belong to them in 1791 to 1841, and many French Canadians had long felt tired of being a minority (Durocher, 2017). Clearly, Quebec has not yet reached its goal, but in the second referendum in 1995, the number of votes declaring agreement to split was almost 50\% (Smith, 2013, p. 22) indicating that almost half of Quebec people wanted to separate Canada and form their own independent state. 
In previous researches regarding the Quebec movement, there is an attempt to done by previous researcher to map the cost and the benefit of Quebec's nationalism (Guay, 2017), several attempt of connecting the issues of different culture ( Language, Religion, etc.) and the reason to separate (Freake et al., 2011; Paquin, 2018; Zhang, 2016) and the effect of few variables in such as age, periods and cohort towards the movement (Vallée-Dubois et al., 2017). There has not been any previous research that focusing on the impact of this movement towards Canadian domestic politics. In this research, writers are trying to look at this issue from a different point of view where the writers are focusing on how this self-determination movement affected Canadian domestic politics.

\section{Constructivism Approach on Politics of Self-determination}

Garvey's interpretation on constructivism approach on politics of self-determination stresses on the feeling of nationality and the rejection of any kind of supremacy to be the main push for the act of selfdetermination. In his study case, he stated on how white supremacy and the level of degradation towards African-American rights is a huge problem and he argues that diaspora identity, Afro-diasporic as a form of different nationality (Jagmohan, 2020, p. 11). He further argues that this Afro-diasporic nationalism gives the political reasons for considering Afrodiasporic right to self-determination in order to secure lives, maintaining rights and promote the black community (Jagmohan, 2020, pp. 2324).

A lot of different separatist movement in the world held a different type of movements in the effort to gain their political agenda. For instance, the Tuareg movement in Mali took a form of movement which gather a few tribal organization with similarly structured and vision (Lecocq \& Klute, 2013, p. 425) which is kind of similar with the Kuki-Chin movements in India and Burma which can be classified as ethnonationalist movement hence the lack of pursuing political powers (Haokip, 2015). In term of structure, Quebec movement is almost similar to the Faroe Island's movement in Denmark since both of these movements took a form primordial politics (Parti Quebecois of Quebec and Løgtingið of Faroe Island) in which both political parties trying to gain their politically-cultural agenda by gaining political power in their own countries through elections and getting seat in the parliament (Adler-Nissen, 2014, p. 58; Archibald, 2020). 
There are quite few researches already regarding numerous movements done by $\mathrm{Al}$ Qurtuby (2015), Lecocq and Klute (2013), and Adler-Nissen (2014). The finding of Al Qurtuby (2015) is that there is a link between political and economic dissatisfaction with the rise of selfdetermination movement in Turkey's PKK and Indonesia's GAM (Al Qurtuby, 2015). Lecocq and Klute (2014) found that the movement in Mali by the Tuareg separatist group occurred because the government didn't facilitate the minority muslim group in the region (Lecocq \& Klute, 2013). Adler-Nissen (2015) in her study of Faroe Island's movement in Denmark found that such movement exists because there's a historical aspect where Faroe Island today is a result of colonization by Denmark and there's a different cultural aspect from Faroe Island and Denmark that fueled the movement to separate (Adler-Nissen, 2014).

Parti Quebecois has held 2 independence referendum in 1980 and 1995. This independence referendum was what the Parti Quebecois promised to the people of quebec during its campaign to get seats in the provincial election in 1976 (Yale \& Durand, 2011, p. 243). Before this agenda, the Quebec nationalist cannot hold referendum since they rarely have any seats at the provincial legislative. Over the past 50 years, Quebec has repeatedly given ultimatums to all countries: "Give us more, or we're leaving!" After two Quebec referendums (in 1980 and 1995) and national referendums (1992), after many conferences, reports, and the constitutional debate that has dominated by Canadian political landscape for more than a generation, Quebec has remained dissatisfied, but has not yet separated (Guay, 2017, p. 1). Therefore, purpose of this article is to examine how much identity issues in the people of Quebec fueled the spirit of self-determination and affect Canada domestic politic.

\section{Methods}

To analyze the problem shown in this paper, the qualitative method is being used where writers gather data through previous studies such us observation, books, International Journals, Conference proceedings, and various websites. Qualitative methods are used to obtain in-depth data, a data that contains meaning. Meaning is actual data, definite data which is a value behind the visible data (Nurdin \& Si, 2019, p. 41).

The use of qualitative method in this paper conducted by literature studies through library and online research, then picking some international journals and books 
related about the issue of selfdetermination and separatism in Quebec and eliminating the previous studies and data that are irrelevant to this particular paper, and comparing the relevant data to be used in this study.

This study will also use interpretive paradigm which a research paradigm that is based on the assumption that social reality is neither singular nor objective, but it's rather shaped by human experiences and social contexts, and is therefore best studied within its socio-historic context by reconciling the subjective interpretations of its various participants (Schwartz-shea \& Yanow, 2012). In interpretive paradigm, we start with data and tries to derive a theory about the phenomenon of interest from the observed data instead of the other way around.

\section{RESULT ANALYSIS AND DISCUSSION \\ French Canadian as A New Identity}

French speaking Québécois was vulnerable in the economy and society field. There are very few of French Canadian Business owner, and the economic decision was made by the Anglophone elite. There was only one out the 11 biggest industrial company that was owned by a French Canadians, the rest were English
Canadian's owned business, and a lot of local French Canadian manifacturing in Quebec composed by small business place (Zhang, 2016, p. 220).

Before the 1960s, most of the Quebec economy was filled by the English Canadian domination $(83 \%$ of executives \& managers were English speaker) and French Canadian got salaries at $35 \%$ lower compared to the Anglophones average and bilingual French Canadians had much lower salaries than unilingual Anglophones (Rocher, 2014, p. 29). Francophone have this shared believe regarding a colonialism from within that was based from cultural and background division of labour (Rocher, 2014, p. 29).

Ergo, the quebec's proindependence movement has a goal to bring a strand of social change and to have more control from the biggest France speaker in the entire North America. It's very clear that language has such important role in a process of making and determining national identity. The ability of being able to share a same language in common makes people feel like a part of national community or the feeling of belonging to the people that has shared culture through history and/or politics (Paquin, 2018, p. 3). 
Even though French is a minority language in Canada and the English language is the majority in the rest of the country, Canada is categorized as a bilingual state. There are approximately 5,231,500 people that were bilingual, which is a lot more comparing with 4,841,300 bilingual speaker in 1996 which there is an increase of $8.1 \%$ (Statistics Canada, 2017). Back in 2001, these people represented at least $17.7 \%$ of Canada population, which is an improvement compared from $17.0 \%$ in 1996. On a national scale, $43.4 \%$ of France speaker said that they were bilingual, compared with $9.0 \%$ of Anglophones (Office of the Commissioner of Official Languages, 2011). In Quebec, the growth in the bilingualism rate from 1996 to 2001 was even bigger than in the previous five-year period (Statistics Canada, 2017).

A while ago, the Quebec government had an attempt in order support the "equal status" of the French language by declaring a law. A regulation was made which required all public signs in Quebec to strictly use Frence that shows the ability of government of Quebec to maintain French culture of Quebec in the country of majority Anglophone Canada (Mahéo \& Bélanger, 2018, p. 7).
But Anglophones in Quebec and the rest of Anglophones in Canada felt that these signs and laws are just an assault on individual rights. In 1988, the Canadian Supreme Court ruled the law of signs in French only saying this law and signs are a violation of Quebec's Charter of Human Rights. Montreal, which is the capital of Anglophones and Francophone interaction in North America could be seen as a battleground between the Francophone and the French culture of Quebec and the Anglophone Canadians with the Americans who's around the French Canada.

Throughout French Canadian history, language has become an important symbol of national identity. However, concerns over the vitality of the French language certainly led to the introduction of the Quebec French Charter (1977), which made French the language of government, public administration, the legislature and the Quebec court (Freake et al., 2011, p. 26). Importantly, this particular charter let French speakers into having the same perks of speaking their native language as English speakers in their native language. It resulted the improvement of French capital in both provinces and countries, and the Québécois identity label gained prestige as a positive symbol of economic value 
and social status (Freake et al., 2011, p. 27).

The government of Quebec had been compelling on only French language for all the commercial ballot, billboards and sings, but the Federal Supreme Court and Quebec Court of Appeals wouldn't let this into being fruition. Both institutions found that its an act of violation of the right to freedom. A not too controversial similar law managed to get through in 1993 where its a must for French language to be shown along with English in all forms of public or commercial signs (Smith, 2013, p. 4).

However, this particular resolution did not manage to end language crisis. The government kept on making more and more strict local law regarding the issue about Francaphone. The elected PQ representation in the National Assembly, Pauline Marois brought an amendment to the French Provincial Charter that later caused an increasing amount of French's language regulations, including a spread to little business and French based education in school (Smith, 2013, p. 4).

Quebec nationalists wanted to reach some form of better position and status for Quebec: which is a brand new form of corporation and association that is equal to the same level of English Canada, or complete sovereignty as an independent country. During the late 1960s, the movement was motivated generally by the shared belief of a lot of Quebec intellectuals and labor leaders, that the economic difficulties that they're facing was a result caused Anglophone Canadian domination and the only way it could be solved is by terminating the relationship with other provinces in Canada and the federal government. Before the end of the 20th century, economic situation was improving. It motivates linguistic and cultural differences diverse became the main political discourse for the reawakening of Quebec movement in the 1990s (Durocher, 2017).

\section{The Request of Independent}

Prior of having two selfdetermination referendums to separate from Canada and form its own independence state, Quebec until today is still a part of Canada after failed attempts that's been going on since the 1960s.

The time of Quebec's shifting began in the late 1960s which shown by the Québec Liberal Party (QLP) succeeded to win the provincial election and change Quebec's social, education and politics institutions which was very traditional, conservative nationalist ideology (Behiels, 2019; Rocher, 2014, p. 26; 
Yale \& Durand, 2011, p. 243). Since the 60s after the quiet revolution, Quebec has been demanding wether to give the province the status of bigger autonomy and acknowledgement of distinct society or declare the full independence of the province.

The first idea of the Québec movement started with the Rassemblement pour l'Indépendance Nationale (RIN) party in back the 1960s (Yale \& Durand, 2011, p. 243). The word used by this party was "independence." The Parti Québécois (PQ) which is an extension of the Mouvement Souveraineté-Association (MSA) which was the political manifestation of ex minister René Lévesque added an associate factor so that Quebec might have a relationship economically with Canada that led to the "sovereignty-association" (Rocher, 2014, pp. 28-29; Yale \& Durand, 2011, p. 243) .

It wasn't just Quebec's spirit of nationalism that's developing over the 60s but it also added an increasingly significant number of Quebeckers that's demanding for a new level of powers that resulted in the rise of social and political movement wanting Quebec's separation from the federal government. Quebec movement would like to increase their positions as the minority group and became the majority by being an independence state (Changfoot et al., 2012, p. 773; Guay, 2017, p. 10).

On July 24th,1967, General Charles de Gaulle, which was the president of France, proclaimed from the balcony of Montréal's City Hall "Vive le Québec libre" Which resulted a resounding cheer by around 13.000 people who witnessed the speech (Axworthy, 2013). By saying the motto of Québec independence movement, Charles has provoked a diplomatic stir up that ended up in the cancellation of his visit, had initiated French interference in the domestic politic of Canada (Axworthy, 2013). Canadian Prime Minister, Lester B. Pearson gave a warning towards Charles with an official statement. Lester told "The people of Canada are free. Every province in Canada is free. Canadians do not need to be liberated. Indeed, many thousands of Canadians gave their lives in two world wars in the liberation of France and other European countries" (Axworthy, 2013).

The Parti républicain du Québec (PRQ) became an official party in 1966, the Ralliement national (RN) became official in 1966, and The Rassemblement pour l'indépendence $d u$ Québec (RIN) was started around the 1960 which was citizens' movement at first then transformed into an official party in 1963 (Rocher, 2014, p. 27; 
Yale \& Durand, 2011, p. 243). In the 1966 Quebec provincial elections, the $\mathrm{RN}$ and the RIN got an accumulated $8.8 \%$ (Rocher, 2014, p. 27).

An influential, René Lévesque decided to quit the PLQ then later, he created the Mouvement souverainetéassociation (MSU) and in 1968, MSU decided to fuse with the $\mathrm{RN}$ and transform into Parti québécois (PQ). Also in 1968, the RIN asked the members of the parti to join the PQ and the party dismissed. The proindependence ideology in Quebec from the 1960s was one of the part to liberate and emancipate the movement in order to get the power in several factors such as economic, social and cultural development (Yale \& Durand, 2011, p. 243).

In 1979, the officials of Quebec posted its desire called "Québec Canada: A New Deal. The Québec Government Proposal for a New Partnership Between Equals: Sovereignty-Association". In a nutshell, sovereignty-association was suppose to improve Quebec's autonomy but to let go part of sovereignty in order to continue to maintain economic with Canada (Rocher, 2014, p. 29).

This new form of association was going to include non barries for import and export, communal transportation unit, labour and monetary union (Rocher, 2014, p. 29). But the sovereignty-association intention didn't get an approval from the other Canadian. Provincial premiers. They refused the intention because it means that Quebec in an even association with the other provinces in Canada. The failure of this intention resulted to the inevitable referendum to separate.

The first referendum of Quebec took place on May 20th, 1980. It was the electoral campaign that PQ promised after the victory of the election in 1976. At the first referendum, nearly $60 \%$ of electors voted no (Rocher, 2014, p. 32; Smith, 2013, p. 8).

The electorate was categorized based on age, employment sector, the language of speaking and education level. Only $48 \%$ of French speaker and $5 \%$ of non-Francophones said yes to the referendum, however, In the 1981 elections, the PQ managed to gain another victory with $49.3 \%$ of the votes and successfully gained 80 out of 122 seats in the Assembly. More than $50 \%$ of the people of Quebec had decided not to leave Canada, but somehow reelected PQ, a nationalist political party to continue their work (Rocher, 2014, p. 33).

In a response to this win, Brian Mulroney, the next prime minister after Pierre Trudeau determned a 
meeting with the other 10 Canadian provinces in order to discuss Québec's demands, which one of them was the acknowledgement that Québec is a "distinct society". This deal "Meech Lake Accord," needed to be voted yes by all 10 provinces before three years to make this deal tur into fruition according to the Constitution Act, 1982 "unanimity procedure."(Yale \& Durand, 2011, p. 243). However, during the time that was given, a few out of these 10 provincial governments changed their minds. By June 1990 which the deadline for the deal, three out of ten provinces had either decided to abstain or voted no on the agreement. This was generally caused because Québec is lacking flexibility and doesn't really has tolerance to the rest of Canada. The failure of the Meech Lake Accord was followed by another attempt of negotiations which ended up with an agreement called the "Charlottetown Accord" which was signed in August 1992 and yet again, it failed to satisfy Quebec's demand (Smith, 2013, pp. 8-9; Yale \& Durand, 2011, pp. 243-244).

After the two failed accords, the Parti Québécois held another referendum related to independence. In the 1994 Quebec provincial election, the people of Quebec put the PQ to the main political position with a majority of PQ members gaining seats at the front row lead by Jacques Parizeau who gave a promise to give voters another referendum in the first year of his term. The 1995 referendum came from an agreement surrounding these pro independence Quebec parties. The agreement was titled "Text of the Agreement" that was made by 3 political parties which are Parti Québécois, Bloc Québécois and Action Démocratique du Québec (Archibald, 2020).

At first, the polls gathered till almost the closing time for voting this second referendum, it showed yes victory (53\%) (Smith, 2013, pp. 2122 ), but the second referendum of Quebec got rejected once again by a rather slim margin $(1.16 \%)$, with $50.58 \%$ voting no $93.52 \%$ of the legal population in quebec voted (Smith, 2013, p. 22). Like the referendum back in 1980, a lot of France speaker voted for independence. Almost $60 \%$ of Francophones voted yes but still couldn't save the $50 \%$ margins that needed to declare an independent (Rocher, 2014, p. 39; Smith, 2013, p. 22).

After the second referendrum, there's been a decrease in the movement of Quebec. This proved by Quebec Liberal Party, which is PQ main opponent and a federal pro political party won in 2008 which was the party's third won since 2003 
(Changfoot et al., 2012, p. 769). But it doesn't necessarily mean the movement's dead. Quebec movements saw its 2 losts to changed the direction into becoming a new project to gain social justice for the French Canadian minority, addressing poverty, redistribution of wealth and radical democratic politics to include more French Canadian in the political sphere (Changfoot et al., 2012, p. 770). Also, Québec has 29 offices in foreign countries, including a Paris office whose status approaches that of an embassy and In 2016-2017, the Québec government organized 1,575 meetings with "influential personalities," more than 1,350 activities to promote and communicate the international policy of Québec, more than 120 solidarity projects in 19 countries, and 273 bilateral cooperation projects in 18 countries and regions (Paquin, 2018, p. 4).

\section{The Middle Way}

In order for a self-determination agenda to be reckon with internationally, it needs the international support to help putting their agendas on track. In the case of Faroe Island's agenda, The UN Human Rights Committee has been the main supporter shown by several criticism towards Denmark for not allowing Faroe Island to held self- determination refrendrum (AdlerNissen, 2014, p. 63). GAM agenda is funded and trained militarily by Libya and Iran (Al Qurtuby, 2015, p. 135).

Whereas, Quebec Nationalistic is heavily depending on provincial nationalistic rather than Canada's nationalistic and Quebec's nationalism has changed in the $60 \mathrm{~s}$ such us from ethnic point of view, "French Canadian" nationalism changed to "Québécois" nationalism and from religious to secular and the Quebec movement supported by France during that period of time proven by the speech given by the president of France Charles de Gaulle exclaiming the Quebec movement's slogan. This group believes that the best way to preserve their Québécois /French Canadian existence and to end economic discrimination by the majority of English descendant and speaker (Anglophone) is by declaring the independence (Guay, 2017, p. 10). Other distinguishing factors, such as religious differences where Quebec is predominantly Catholic and the majority of Canadian people are Protestant or Christian, are also used to justify the movement in Quebec.

Parti Quebecois has been the biggest form of Quebec independence movement. This political parti has held twice referendum and managed to get a lot of attention from the people of 
Quebec and the rest of Canada. Former prime minister Pierre Elliott Trudeau stated that Quebec nationalism (Parti Quebecous) is a separatist movement that really is a blackmailer that's always asking more and more and it's never enough (Guay, 2017, p. 2).

This movement has caused quite a turmoil to Canadian domestic politic over the last few decades, where the Canadian federal government are forced to either listen to Quebec nationalist or lose a province. The fear of losing has led former Prime Minister Pierre Elliott Tredeau to take a serious attempt to prevent Parti Quebecious to hold referendum to left Canada. Pierre Elliott Trudeau ended up inventing a specific working group filled with some senior officials that have a mission to promote national unity in Canada. The Canadian Unity Information Office (CUIO) made in 1977 to promote pro-federalist propaganda. This working group has several duties such as collecting Canadians' advice regarding what's the best solution to deal with threats linked with national unity (Rocher, 2014, p. 28). The working group made a result in 1979 which they found that the Canada federalism had to shift to even up both the proportion of regional differences and Canadian duality status. Solutions given by Canadian composed of more autonomy of the central government by lowering Canada's spending also using an uneven way from one province to another in order to maintain and preserve Quebec's distinct character (Rocher, 2014, p. 28).

\section{Conclusions}

The Quebec movement that demands for larger provincial autonomy has putted Canada domestic politic under chaos over the last few decades. There are two main challange for Canadian goverment regarding the Quebec Issues: first, new identity and nationalism of France Speaker and second, is the request of independent. The new identity in Quebec resulted in descrimination towards non french speaker both in Quebec and Canada as a whole and the request independent that has resulted in 2 referendums has put Canada's national unity on peril.

This paper found that the French Canadian feels this solidarity and shared belonging that they've been wronged by the Anglophone Canadian for ages which resulted in a shared belive among these French Canadian based on the fact there was a social and economical structure that placed them on the bottom and the Anglophone on top of the structure. 
This feeling of shared believe created a form of an identity. Quebec's French Canadian have the shared feeling that they differ than the rest of Canada based on their cultural background as a distinctive ethnic. They feel minoritized in their own country and don't feel like they belong as a Canadian

Quebec identity then evolved into a form of nationalism where the French Canadian belive the only way to preserve their "distinc" culture by seperating their teritorial from the majority English Speaking Canada and declare their indepence to in order to not being a minority again. It is quite interesting to note that even a highly developed country like Canada, faced with nationalist agenda, which means nationalist is still relevant in Canada.

\section{References}

Adler-Nissen, R. (2014) "The Faroe Islands: Independence dreams, globalist separatism and the Europeanization of postcolonial home rule", Cooperation and Conflict, 49(1), 55-79.

https://doi.org/10.1177/00108367135 14150

Al Qurtuby, S. (2015) "Interethnic violence, separatism and political reconciliation in Turkey and Indonesia", India Quarterly, 71(2), 126-145. https://doi.org/10.1177/09749284145 68619

Archibald, C. and M.-E. L. (2020) Parti Québécois (Online). Available at: https://thecanadianencyclopedia.ca/en /article/parti-quebecois

Axworthy, T. S. (2013) General De Gaulle and "Vive le Québec libre" (Online). Available at:

https://www.thecanadianencyclopedia. $\mathrm{ca} / \mathrm{en} /$ article/de-gaulle-and-vive-lequebec-libre-feature

Behiels, M. D. (2019) Quebec - The "Quiet Revolution" to the present (Online). Available at: https://www.britannica.com/place/Q uebec-province/The-QuietRevolution-to-the-present

Changfoot, N., Cullen, B., Studies, I., \& Uni-, T. (2012) Changfoot \& Cullen Quebec separatism - reducing national unity crisis - neoliberal - 2011. 4, 769-787.

Durocher, R. D. M. (2017) Quiet Revolution | Canadian history (Online). Available at: https://www.britannica.com/topic/Q uiet-Revolution

Freake, R., Gentil, G., \& Sheyholislami, J. (2011) "A bilingual corpus-assisted discourse study of the construction of nationhood and belonging in Quebec", Discourse and Society, 22(1), 21-47. https://doi.org/10.1177/09579265103 82842

Guay, J.-H. (2017) 'Sovereignty at an Impasse: The Highs and Lows of Quebec Nationalism', IRPP Insight, 18, 1-30.

Haokip, T. L. (2015) "Ethnic Separatism: The Kuki-Chin Insurgency of IndoMyanmar/Burma", South Asia Research, 35(1), 21-41. https://doi.org/10.1177/02627280145 60473

Jagmohan, D. (2020) "Between Race and Nation: Marcus Garvey and the Politics of Self-Determination", Political Theory, 48(3), 271-302. https://doi.org/10.1177/00905917198 97569

Judt, T., \& Lacorne, D. (2004) Language, Nation, and State: Identity Politics in a 
Multilingual Age (T. J. D. Lacorne (ed.)). Palgrave Macmillan.

http://library1.nida.ac.th/termpaper6/ sd/2554/19755.pdf

Lecocq, B., \& Klute, G. (2013) "Tuareg Separatism in Mali", International Journal, 68(3), 424-434.

https://doi.org/10.1177/00207020135 05431

Mahéo, V. A., \& Bélanger, É. (2018) "Is the Parti Québécois Bound to Disappear? A Study of the Current Generational Dynamics of Electoral Behaviour in Quebec", Canadian Journal of Political Science, 51(2), 1-22. https://doi.org/10.1017/S0008423917 001147

Nurdin, D. I., \& Si, M. (2019) Metodologi Penelitian Sosial (S. H. Lutfiah (ed.)). Media Sahabat Cendekia.

Office of the Commissioner of Official Languages. (2011) OCOL - Statistics on Official Languages in Quebec (Online). Available at: https://www.cloocol.gc.ca/html/quebec_e.php

Paquin, S. (2018) "Identity Paradiplomacy in Québec", Quebec Studies, 66(14), 3-26. https://doi.org/10.3828/qs.2018.21

Parti Québécois. (2020) Pourquoi le gouvernement s'acharne-t-il sur les familles? Parti Québécois (Online). Available at: https://pq.org/nouvelles/pourquoi-legouvernement-sacharne-t-il-sur-lesfam/

Rocher, F. (2014) "Self-determination and the Use of Referendums: The Case of Quebec", International Journal of Politics, Culture and Society, 27(1), 25-45. https://doi.org/10.1007/s10767-0139167-2

Schwartz-shea, P., \& Yanow, D. (2012) Interpretative Research Design: Concepts and
Processes. Routledge: London \& New York.

Smith, B. (2013) The Quebec Referendums

(Online). Available at:

http://kms2.isn.ethz.ch/serviceengine /Files/ESDP/167605/ipublicationdoc ument_singledocument/116278421436-48a8-a2a153350eb60ba5/en/RP13-47.pdf

Statistics Canada. (2017) Census Profile, 2016 Census - Quebec [Province] and Canada [Country] (Online). Available at: https://www12.statcan.gc.ca/censusrecensement/2016/dp-

$\mathrm{pd} /$ prof/details/page.cfm?Lang $=\mathrm{E} \& \mathrm{G}$ eo1 $=$ PR $\&$ Code $1=24 \& G e o 2=$ PR $\&$ Cod $\mathrm{e} 2=01 \&$ Data $=$ Count $\&$ SearchText $=$ qu ebec\&SearchType $=$ Begins\&SearchPR $=01 \& \mathrm{~B} 1=$ Language $\& \mathrm{TABID}=1$

Vallée-Dubois, F., Dassonneville, R., \& Godbout, J.-F. (2017) "About Time: Age, Period, and Cohort Effects on Support for Quebec Sovereignty", Nations and Nationalism. https://doi.org/10.1111/nana.12378

Yale, F., \& Durand, C. (2011) "What Did Quebeckers Want? Impact of Question Qording, Constitutional Proposal and Context on Support for Sovereignty, 1976-2008", American Review of Canadian Studies, 41(3), 242-258. https://doi.org/10.1080/02722011.20 11.594517

Zhang, K. (2016) "French Speaking on the Situation of Multiculture and Nationalism in Quebec During 1980 2010", Procedia - Social and Behavioral Sciences, 236, 219-224. https://doi.org/10.1016/j.sbspro.2016 .12 .010 